\title{
Soil Properties under Selected Homestead Grown Indigenous Tree and Shrub Species in the Highland Areas of Central Ethiopia
}

\author{
Kindu Mekonnen ${ }^{1 *}$, Gerhard Glatzel ${ }^{2}$, Monika Sieghardt ${ }^{2}$ and Ottner Franz ${ }^{3}$ \\ ${ }^{1}$ Holetta Agricultural Research Center, P O Box 2003, Addis Ababa, Ethiopia \\ 2Institute of Forest Ecology, UNI BOKU, Peter-JordanStrasse 82, A-1190, Vienna, Austria \\ ${ }^{3}$ Institute of Applied Geology, UNI BOKU, Peter-Jordan Strasse 70, A-1190, Vienna, Austria
}

\begin{abstract}
A study was conducted in Galessa-Jeldu areas to evaluate soil $\mathrm{pH}$, organic $\mathrm{C}$, total $\mathrm{N}$, available $\mathrm{P}$ and exchangeable bases under four indigenous and one exotic tree species, and to examine the correlation between the different soil properties. The tree and shrub species included in the study were Senecio gigas Vatke, Hagenia abyssinica (Bruce) J.F. Gmel., Dombeya torrida (J.F. Gmel.) P. Bamps, Buddleja polystachya Fres. and Chamaecytisus palmensis (Christ) Bisby and $\mathrm{K}$. The first four are indigenous, while the last one is an exotic $\mathrm{N}$-fixing species. The soil $\mathrm{pH}$ values under $H$. abyssinica and $S$. gigas were above 6.34 as compared to the soil $\mathrm{pH}$ values under $C$. palmensis, $D$. torrida and B. polystachya. Total $\mathrm{N}$ was slightly higher under $H$. abyssinica although not statistically different with the $\mathrm{N}$ content under other species. Organic $\mathrm{C}$ was higher under $H$. abyssinica than under $B$. polystachya. The variation for exchangeable $\mathrm{K}$ was more at $0-15 \mathrm{~cm}$ soil depth than at the $15-30$ and $30-50 \mathrm{~cm}$ soil depths. The correlation between soil $\mathrm{pH}$ and total $\mathrm{N}$ as well as $\mathrm{pH}$ and organic $\mathrm{C}$ was positive in almost all the horizontal positions. Hagenia abyssinica, S. gigas and C. palmensis are some of the potential species that can be evaluated in different land-use systems of the high altitude areas to protect the loss of plant nutrients.
\end{abstract}

Keywords: High Altitude; Total N; Organic C; Exchangeable Bases; Soil Fertility; Nutrient Cycling

\section{Introduction}

High human and livestock population, a decline of forest resources and soil fertility depletion are some of the features of the highlands of central Ethiopia (ICRAF, 1990; German et al., 2005; Amare et al., 2006). The natural forests in the highlands of Ethiopia in general are heavily exploited to fulfill the cash and wood demand of the growing population. Similarly, the areas previously covered by forests have declined as a result of the expansion of farming with annual crops. Homesteads are one of the most important niches in which farmers feel confident to plant and maintain tree and shrub species.

Homesteads in the high altitude (> 2900 m.a.s.l) areas of central Ethiopia have a better tree and shrub species composition than farmlands (Kindu et al., 2006a). The proportion and area coverage of indigenous species around the homesteads is also considerable as compared to exotic species. The increased proportion of indigenous species over the exotics is due to their adaptability to the local environmental conditions, resistance to pests and diseases, availability as sources of planting material and familiarity to the local farmers. Farmers grow tree and shrub species around homesteads to obtain various products (wood, food and feed) and services (live fence, shade and soil fertility improvement) (Berhane et al., 2006).

Farmers in the high altitude areas highly recognize Hagenia abyssinica, Dombeya torrida and Senecio gigas as important indigenous soil improving tree and shrub species (Kindu et al., 2006a). The contribution of some other indigenous tree species for soil fertility improvement in farmlands has been investigated in the intermediate altitude (1500-2400 m.a.s.l) areas of Ethiopia by Abebe et al. (2001); Yeshanew et al. (1999); Hailu et al. (2000); Poschen (1986) and Gindaba et al. (2005). Assessments of the soil properties under and away from the tree canopies were the focus of all of the studies. The report from most of the previous studies show a higher soil organic matter, total $\mathrm{N}$ and other soil attributes under the tree canopies than in open areas.

*Corresponding author. E-mail: kindumeko@yahoo.com
Studies on soil properties under farmers' recognized indigenous tree and shrub species around homesteads are limited in the high altitude areas. Cognizant to the research gap, a study was conducted from 2004 to 2006 (a) to evaluate soil $\mathrm{pH}$, organic $\mathrm{C}$, total $\mathrm{N}$, available $\mathrm{P}$, exchangeable bases under four indigenous and an exotic tree species; and (b) to examine correlations between the different soil properties.

\section{Materials and Method 2.1. Study Site}

The study was conducted from 2004 to 2006 in the upper plateaus of Galessa-Jeldu areas, Dendi and Jeldu districts, central Ethiopia (9० $02^{\prime} 47^{\prime \prime}$ to $9^{\circ} 1^{\prime} 15^{\prime} 00^{\prime \prime} \mathrm{N}$ and $38^{\circ} 05^{\prime}$ $00^{\prime \prime}$ to $\left.38^{\circ} 12^{\prime} 16^{\prime \prime} \mathrm{E}\right)$. The altitude ranges from 2900 to 3200 m.a.s.l. The rainfall pattern is bimodal. The main rainy season is from June to September and the short rainy season from March to April with a mean annual rainfall of $1399 \mathrm{~mm}$. Barley is the most dominant crop followed by potato and enset (Ensete ventricosum). The most common land-use systems in the study areas are crop, pasture and forest. Trees and shrubs are concentrated around the homestead and the nearby Chilmo state forest. The original vegetation in the area was mainly $H$. abyssinica and Juniperus procera. The exotic tree and shrub species introduced in the area include C. palmensis and Acacia decurrens. Cattle, sheep and horses are dominant livestock in the study area. The soil is characterized as Haplic Luvisols. The physical and chemical properties of the soil are presented in Table 1.

\subsection{Selection of the Tree and Shrub Species}

A total of 150 households were interviewed to find out indigenous tree and shrub species that are traditionally considered by farmers as important soil fertilizers. Subsequently the farmers were asked to describe the type of tree and shrub species that they consider important. The most important tree and shrub species for the farmers were species that regularly shed their leaves, have fast decomposing leaves, grow fast, propagate easily, produce high biomass, and protect soil erosion. Finally, farmers selected Senecio gigas Vatke, Hagenia abyssinica 
(Bruce) J.F. Gmel, Dombeya torrida (J.F. Gmel.) P. Bamps and Buddleja polystachya Fres (Kindu et al., 2006a). Three villages that had all the required indigenous species were identified. Tree and shrub species free from addition of farm weeded material; manure or house wastes and inorganic fertilizers were selected and demarcated in each village. The three villages were considered as replications.
Most tree and shrub species in the village exist in hedges. A total of three trees per indigenous and exotic species (Chamaecytisus palmensis (Christ) Bisby and K. Nicholls) were included in the present study. The exotic tree species was used for comparison purposes. Detailed description of the species is presented in Table 2 .

Table 1. Some physical and chemical properties of the soil in the Galessa-Jeldu area.

\begin{tabular}{|c|c|c|c|c|c|c|c|}
\hline Depth (cm) & $\mathrm{pH}\left(\mathrm{H}_{2} \mathrm{O}\right)$ & $\mathrm{OC}\left(\mathrm{mg} \mathrm{g}^{-1}\right)$ & Tot. $\mathrm{N}\left(\mathrm{mg} \mathrm{g}^{-1}\right)$ & Av. P $\left(\mathrm{mg} \mathrm{g}^{-1}\right)$ & Sand $(\%)$ & Silt $(\%)$ & Clay $(\%)$ \\
\hline $0-18$ & 6.28 & 48.280 & 4.796 & 0.083 & 12 & 47 & 41 \\
\hline $18-60$ & 6.19 & 15.290 & 1.316 & 0.018 & 11 & 37 & 52 \\
\hline $60-125$ & 5.66 & 4.356 & 0.459 & 0.021 & 4 & 34 & 62 \\
\hline $125-160$ & 5.97 & 2.027 & 0.198 & 0.022 & 28 & 33 & 39 \\
\hline
\end{tabular}

Tot. $N$ - total N, OC - organic C, Av. P - available $P$

Table 2. Description of the tree and shrub species considered for the study.

\begin{tabular}{llllll}
\hline Species & Familly name & Estimated age (year) & Propagation & Height (m) & $\begin{array}{l}\text { Average crown } \\
\text { diameter }(\mathrm{m})\end{array}$ \\
\hline Hagenia abyssinica & Rosaceae & $5-8$ & Seed & $4.0-4.6$ & 2.5 \\
Dombeya torrida & Sterculiaceae & $6-8$ & Seed & $4.3-5.0$ & 2.3 \\
Buddleja polystachya & Loganiaceae & $5-9$ & Seed, cutting & $3.1-4.6$ & 2.2 \\
Chamaecytisus palmensis & Fabaceae & $4-5$ & Seed & $4.5-4.9$ & 2.4 \\
Senecio gigas & Asteraceae & $5-8$ & cutting & $2.7-3.5$ & 1.8 \\
\hline
\end{tabular}

\subsection{Soil Sampling and Analysis}

A radial pattern of soil sampling was used. Sampling locations were $75 \mathrm{~cm}$ (hereafter referred to as closest), $150 \mathrm{~cm}$ (hereafter referred to as midst), and $225 \mathrm{~cm}$ (hereafter referred to as distant) positions at both sides from the base of each marked tree (Hailu et al., 2000; Wezel, 2000; Power et al., 2003). Sampling depths were 0$15,15-30$ and $30-50 \mathrm{~cm}$ (Kindu et al., 1997). Soil samples collected under each species and village from similar depths and positions were thoroughly mixed to obtain composite samples. The total number of composite samples was 135 (Soil improving tree and shrub species (5) * depths of sampling (3) * distances of sampling from the base of the tree (3)* replications (3)).

The soil $\mathrm{pH}$ was determined in 1:2.5 soil suspensions in deionised water for active acidity using potentiometric pH-Meter (ÖNORM L1083, 2005). Organic carbon was determined by C/S-Element Analyzer LECO S/C 444 using oven-dry samples. Dry combustion at $1400{ }^{\circ} \mathrm{C}$ in pure $\mathrm{O}_{2}$ atmosphere and infrared detection of evolved $\mathrm{CO}_{2}$ was applied (ÖNORM L1080, 2005). Total nitrogen was determined by semi-micro-Kjeldahl procedure using the air-dry samples. Wet combustion of air-dry soil samples was carried out with $\mathrm{H}_{2} \mathrm{SO}_{4}(98 \%)$ and a catalyst containing $\mathrm{K}_{2} \mathrm{SO}_{4}$ and $\mathrm{CuSO}_{4}$ at $400{ }^{\circ} \mathrm{C}$. Automatic vapour distillation with saturated $\mathrm{NaOH}$ and titration of evolved $\mathrm{NH}_{3}$ using a Kjeltec Auto 2300, (TECATOR) with automatic calculation device was used (ÖNORM L1082, 2005).

Available P was determined by Olsen method (Olsen and Sommers, 1982). Exchangeable element contents $\left(\mathrm{K}^{+}, \mathrm{Ca}^{2+}, \mathrm{Mg}^{2+}, \mathrm{Mn}^{2+}\right.$ and $\mathrm{Al}^{3+}$ ) were determined by extraction of air-dried samples with $0.1 \mathrm{M} \mathrm{NH}_{4} \mathrm{OAc}$ at $\mathrm{pH}$
7.0. Determination of the exchangeable elements was carried out using a simultaneous ICP-OES (Inductively Coupled Plasma - Optical Emission Spectroscopy) with an axial plasma (Perkin Elmer, OPTIMA 3000 XL). The determinations were made after calibration with matrixadapted standard solutions (ÖNORM L1085, 2004). Cation Exchange Capacity (CEC) and \% base saturation (BS) were calculated as follows:

$\mathrm{CEC}\left(\mathrm{mmol}_{\mathrm{c}} / 100 \mathrm{~g}\right)=\mathrm{K}(\mathrm{ppm}) / 390+\mathrm{Mg}(\mathrm{ppm}) / 120$

$+\mathrm{Ca}(\mathrm{ppm}) / 200+\mathrm{Na}(\mathrm{ppm}) / 230+\mathrm{H}($ buffer $\mathrm{pH})--(1)$

$\mathrm{BS}=(\mathrm{Base}(\mathrm{meq} / 100 \mathrm{~g}) / \mathrm{CEC}) * 100$--------------- $(2)$

\subsection{Statistical Analysis}

A one-way analysis of variance (ANOVA) was conducted on soil $\mathrm{pH}, \mathrm{OC}, \mathrm{N}$ and exchangeable bases. The effect of depths and positions, and their interactions on soil properties was conducted following the procedures of liner models ANOVA. Both analysis were run using SAS (SAS institute, 1999). The significance between means was tested using the least significance difference (LSD). The following model was considered while running the ANOVA:

$Y_{i j}=\mu+a_{i}+\beta_{j}+e_{i p}$------------ (3) where $\mu$ is the overall mean, $a_{i}$ the $i$ th treatment (tree species) effect, $\beta_{j}$ the $j$ th block (site) effect and $e_{i j}$ is the random error associated with $Y_{i j}$.

Correlation analysis was performed to understand the relation between OC vs $\mathrm{N}$; $\mathrm{pH}$ vs $\mathrm{OC}, \mathrm{N}, \mathrm{Al}, \mathrm{Mn}, \mathrm{BS}$ and CEC. Levels of $\mathrm{P}<0.05, \mathrm{P}<0.01$ and $\mathrm{P}<0.001$ were chosen to test significance differences. 


\section{Results}

\subsection{Soil $\mathrm{pH}$, Organic $\mathrm{C}$, Total $\mathbf{N}$ and Available $\mathbf{P}$}

Soil $\mathrm{pH}$ at the depth of $0-15 \mathrm{~cm}$ varied horizontally from 6.01 to $6.8,5.9$ to 6.7 and 5.85 to 6.95 in the closest, midst and distant positions, respectively (Table 3 ). The soil $\mathrm{pH}$ values under $H$. abyssinica and $S$. gigas were above 6.34 as compared to the soil $\mathrm{pH}$ values under $C$. palmensis, $D$. torrida and B. polystachya. The $\mathrm{pH}$ values under the five tree and shrub species varied significantly among the soil depths (Table 3 and 4). Higher $\mathrm{pH}$ values were found at the topsoil than that of lower depths. Similarly, the soil $\mathrm{pH}$ varied along the three horizontal positions. Higher $\mathrm{pH}$ values were noticed in the closest position than in the midst and the distant positions.

The soil OC and $\mathrm{N}$ content under $H$. abyssinica, S. gigas, C. palmensis and D. torrida were comparable in the top 0-15 $\mathrm{cm}$ depth (Table 3). On the other hand, the soil OC content under $H$. abyssinica was higher by 23.25, 24.53 and $21.03 \mathrm{mg} \mathrm{g}^{-1}$ than under B. polystachya in the closest, midst and distant positions, respectively. Total $\mathrm{N}$ was slightly higher under $H$. abyssinica although not statistically different with the $\mathrm{N}$ content under other species. The content of soil $\mathrm{P}$ had the following sequence in the top 0 $15 \mathrm{~cm}$ soil depth of the closest and midst horizontal positions: $H$. abyssinica $>S$. gigas $>C$. palmensis $>D$. torrida $>$ B. polystachya (Figure 1). Organic C, N and P showed significant differences among the soil depths, as well as the horizontal positions (Table 4). The content of OC, N and $\mathrm{P}$ depicts a decreasing pattern from the $0-15$ to the $30-50 \mathrm{~cm}$ soil depths and from the closest to the midst and distant positions.

\subsection{Exchangeable Bases}

The variation for exchangeable $\mathrm{K}$ and $\mathrm{Ca}$ was high at 0-15 $\mathrm{cm}$ soil depth than at the 15-30 and 30-50 cm soil depths (Table 5). The soil under $H$. abyssinica, $S$. gigas and $C$. palmensis had a high content of soil $\mathrm{K}$ and $\mathrm{Ca}$ as compared to the soil under B. polystachya and $D$. torrida. The $\mathrm{Mg}$ content under $H$. abyssinica and $S$. gigas was high as compared to the $\mathrm{Mg}$ content under other species in all the soil depths and horizontal positions. The content of $\mathrm{K}$, $\mathrm{Ca}$ and $\mathrm{Mg}$ varied at the three soil depths of the closest, midst and distant horizontal positions, i.e. it decreased from the top to the lower soil depths and from the closest to the midst and distant positions.

\subsection{Cation Exchange Capacity}

The CEC values under $H$. abyssinica and $S$. gigas were higher at the three soil depths of all the horizontal positions (Figure 2). The soil under C. palmensis had higher CEC values than under B. polystachya and $D$. torrida. The lowest CEC values were recorded under $B$. polystachya at the $0-15$ and $15-30 \mathrm{~cm}$ soil depths of all the three horizontal positions.

\subsection{Correlation between Soil Properties}

The correlation between $\mathrm{OC}$ and $\mathrm{N}$ was positive and statistically significant at all the soil depths of the three horizontal positions (Table 6). Soil $\mathrm{pH}$ was positively and significantly correlated with CEC and BS, and negatively and significantly correlated with $\mathrm{Mn}$. The correlation between soil $\mathrm{pH}$ and $\mathrm{N}$ as well as $\mathrm{pH}$ and $\mathrm{OC}$ was positive in almost all the cases. No significant correlation was found between $\mathrm{pH}$ and $\mathrm{Al} ; \mathrm{pH}$ and $\mathrm{OC} ; \mathrm{pH}$ and $\mathrm{N}$, except at the $0-15 \mathrm{~cm}$ soil depth and in the closest position of the five tree species. 
Table 3. Total $\mathrm{N}$, organic $\mathrm{C}$ and $\mathrm{pH}$ at different depths and positions from five tree and shrub species.

\begin{tabular}{|c|c|c|c|c|c|c|c|c|c|c|}
\hline \multirow[b]{2}{*}{ Species } & \multirow{2}{*}{$\begin{array}{c}\text { Depth } \\
(\mathrm{cm})\end{array}$} & \multirow{2}{*}{$\begin{array}{l}\mathrm{pH}\left(\mathrm{H}_{2} \mathrm{O}\right) \\
75 \mathrm{~cm} \text { position }\end{array}$} & \multicolumn{5}{|c|}{ Organic C $\left(\mathrm{mg} \mathrm{g}^{-1}\right)$} & \multicolumn{2}{|l|}{ Total N $\left(\mathrm{mg} \mathrm{g}^{-1}\right)$} & \multirow[b]{2}{*}{$225 \mathrm{~cm}$ positior } \\
\hline & & & $150 \mathrm{~cm}$ position & $225 \mathrm{~cm}$ position & $75 \mathrm{~cm}$ position & $150 \mathrm{~cm}$ position & $225 \mathrm{~cm}$ position & $75 \mathrm{~cm}$ position & $150 \mathrm{~cm}$ position & \\
\hline B. polystachya & 15 & $6.07^{b}$ & $5.90^{c}$ & $5.86^{\mathrm{b}}$ & $51.31^{\mathrm{b}}$ & $40.33^{\mathrm{b}}$ & $39.73^{\mathrm{b}}$ & $4.75^{a}$ & $3.99^{\mathrm{b}}$ & $3.83^{\mathrm{b}}$ \\
\hline C. palmensis & & $6.01^{b}$ & $5.97 \mathrm{bc}$ & $6.09^{b}$ & $61.37 \mathrm{ba}$ & $58.63^{\mathrm{ba}}$ & $56.36^{\mathrm{ba}}$ & $5.92^{\mathrm{a}}$ & $5.74 \mathrm{ba}$ & $5.19 \mathrm{ba}$ \\
\hline D. torrida & & $6.14^{\mathrm{ba}}$ & $5.92^{\mathrm{bc}}$ & $5.85^{\mathrm{b}}$ & $63.50^{\mathrm{ba}}$ & $59.86^{\mathrm{ba}}$ & $57.59^{a}$ & $4.92^{\mathrm{a}}$ & $5.36^{\mathrm{ba}}$ & $5.36^{\mathrm{ba}}$ \\
\hline H. abyssinica & & $6.80^{\mathrm{a}}$ & $6.70^{\mathrm{a}}$ & $6.95^{\mathrm{a}}$ & $74.56^{\mathrm{a}}$ & $64.86^{a}$ & $60.76^{a}$ & $6.60^{\mathrm{a}}$ & $6.26^{a}$ & $5.66^{\mathrm{a}}$ \\
\hline S. gigas & & $6.59^{\mathrm{ba}}$ & $6.47^{\mathrm{ba}}$ & $6.47^{\mathrm{ba}}$ & $58.93^{\text {ba }}$ & $55.11^{\text {ba }}$ & $53.00^{\mathrm{ba}}$ & $5.36^{\mathrm{a}}$ & $5.15^{\mathrm{ba}}$ & $5.04^{\mathrm{ba}}$ \\
\hline SEM & & 0.121 & 0.111 & 0.139 & 3.302 & 3.372 & 2.899 & 0.335 & 0.333 & 0.274 \\
\hline B. polystachya & 30 & $5.77 \mathrm{~b}$ & $5.77 \mathrm{~b}$ & $5.76^{\mathrm{b}}$ & $38.00^{\mathrm{a}}$ & $32.52^{\mathrm{a}}$ & $33.01^{\mathrm{a}}$ & $3.64^{a}$ & $2.66^{a}$ & $3.03^{a}$ \\
\hline C. palmensis & & $5.89^{\mathrm{b}}$ & $5.83^{\mathrm{b}}$ & $6.11^{b}$ & $50.84^{a}$ & $44.82^{\mathrm{a}}$ & $39.34^{\mathrm{a}}$ & $4.94^{a}$ & $3.98^{a}$ & $3.82^{\mathrm{a}}$ \\
\hline D. torrida & & $5.77^{\mathrm{b}}$ & $5.74^{\mathrm{b}}$ & $5.73^{\mathrm{b}}$ & $44.04^{a}$ & $37.70^{a}$ & $38.63^{a}$ & $4.22^{\mathrm{a}}$ & $3.68^{a}$ & $3.68^{a}$ \\
\hline H. abyssinica & & $6.72^{a}$ & $6.59^{a}$ & $6.86^{a}$ & $56.29^{a}$ & $43.92^{\mathrm{a}}$ & $44.42^{a}$ & $5.21^{\mathrm{a}}$ & $4.13^{a}$ & $4.14^{a}$ \\
\hline S. gigas & & $6.39^{\mathrm{ba}}$ & $6.42^{\mathrm{a}}$ & $6.36^{\mathrm{ba}}$ & $43.76^{a}$ & $36.95^{\mathrm{a}}$ & $33.84^{a}$ & $4.07^{\mathrm{a}}$ & $3.28^{a}$ & $2.89^{a}$ \\
\hline SEM & & 0.128 & 0.118 & 0.141 & 3.199 & 2.654 & 2.279 & 0.280 & 0.284 & 0.227 \\
\hline B. polystachya & 50 & $5.71^{\mathrm{b}}$ & $5.74^{b}$ & $5.77 \mathrm{~b}$ & $32.41^{a}$ & $24.96^{a}$ & $21.12^{\mathrm{b}}$ & $2.92^{a}$ & $2.14^{a}$ & $1.96^{\mathrm{b}}$ \\
\hline C. palmensis & & $5.77 \mathrm{~b}$ & $5.79 \mathrm{~b}$ & $5.85^{\mathrm{b}}$ & $29.12^{\mathrm{a}}$ & $26.50^{a}$ & $28.18^{\mathrm{ba}}$ & $2.67^{a}$ & $2.45^{a}$ & $2.51^{\mathrm{ba}}$ \\
\hline D. torrida & & $5.67^{\mathrm{b}}$ & $5.64^{\mathrm{b}}$ & $5.71^{\mathrm{b}}$ & $31.25^{\mathrm{a}}$ & $28.24^{a}$ & $28.49^{\mathrm{ba}}$ & $2.91^{\mathrm{a}}$ & $2.60^{a}$ & $2.28^{\mathrm{ba}}$ \\
\hline H. abyssinica & & $6.50^{\mathrm{a}}$ & $6.52^{\mathrm{a}}$ & $6.75^{\mathrm{a}}$ & $38.37^{a}$ & $35.37^{a}$ & $36.30^{\mathrm{a}}$ & $3.36^{\mathrm{a}}$ & $3.19^{a}$ & $3.19^{a}$ \\
\hline S. gigas & & $6.40^{a}$ & $6.44^{\mathrm{a}}$ & $6.35^{a}$ & $39.37^{a}$ & $22.57^{a}$ & $21.48^{\mathrm{b}}$ & $3.46^{\mathrm{a}}$ & $1.93^{a}$ & $1.91^{\mathrm{b}}$ \\
\hline SEM & & 0.111 & 0.112 & 0.121 & 2.120 & 1.992 & 2.099 & 0.200 & 0.213 & 0.183 \\
\hline
\end{tabular}

Means with different letters within a column at similar depth and position are significantly different $(p<0.05)$.

SEM - Standard error of the means $(n=15)$. 
Table 4. The effect of five tree and shrub species on soil properties at three depths and three horizontal positions.

\begin{tabular}{lccc}
\hline \multirow{2}{*}{ Soil attributes } & \multicolumn{2}{c}{ Effect } & Depth x Position \\
\cline { 2 - 4 } $\mathrm{pH}\left(\mathrm{H}_{2} \mathrm{O}\right)$ & Depth & Position & 0.007 \\
$\mathrm{OC}\left(\mathrm{mg} \mathrm{g}^{-1}\right)$ & 0.000 & 0.002 & 0.821 \\
Tot. $\mathrm{N}\left(\mathrm{mg} \mathrm{g}^{-1}\right)$ & 0.000 & 0.000 & 0.040 \\
Av. P $\left(\mathrm{mg} \mathrm{g}^{-1}\right)$ & 0.000 & 0.000 & 0.043 \\
Exch. $\mathrm{K}\left(\mu \mathrm{g} \mathrm{g}^{-1}\right)$ & 0.000 & 0.000 & 0.000 \\
Exch. $\mathrm{Ca}\left(\mu \mathrm{g} \mathrm{g}^{-1}\right)$ & 0.000 & 0.000 & 0.757 \\
Exch. ${\mathrm{Mg}\left(\mu \mathrm{g} \mathrm{g}^{-1}\right)}_{\mathrm{CEC}\left(\mathrm{mmolc} \mathrm{kg}^{-1}\right)}^{0.000}$ & 0.000 & 0.002 & 0.107 \\
\hline
\end{tabular}

Figures under the depth, position, and depth $x$ position are P-values.
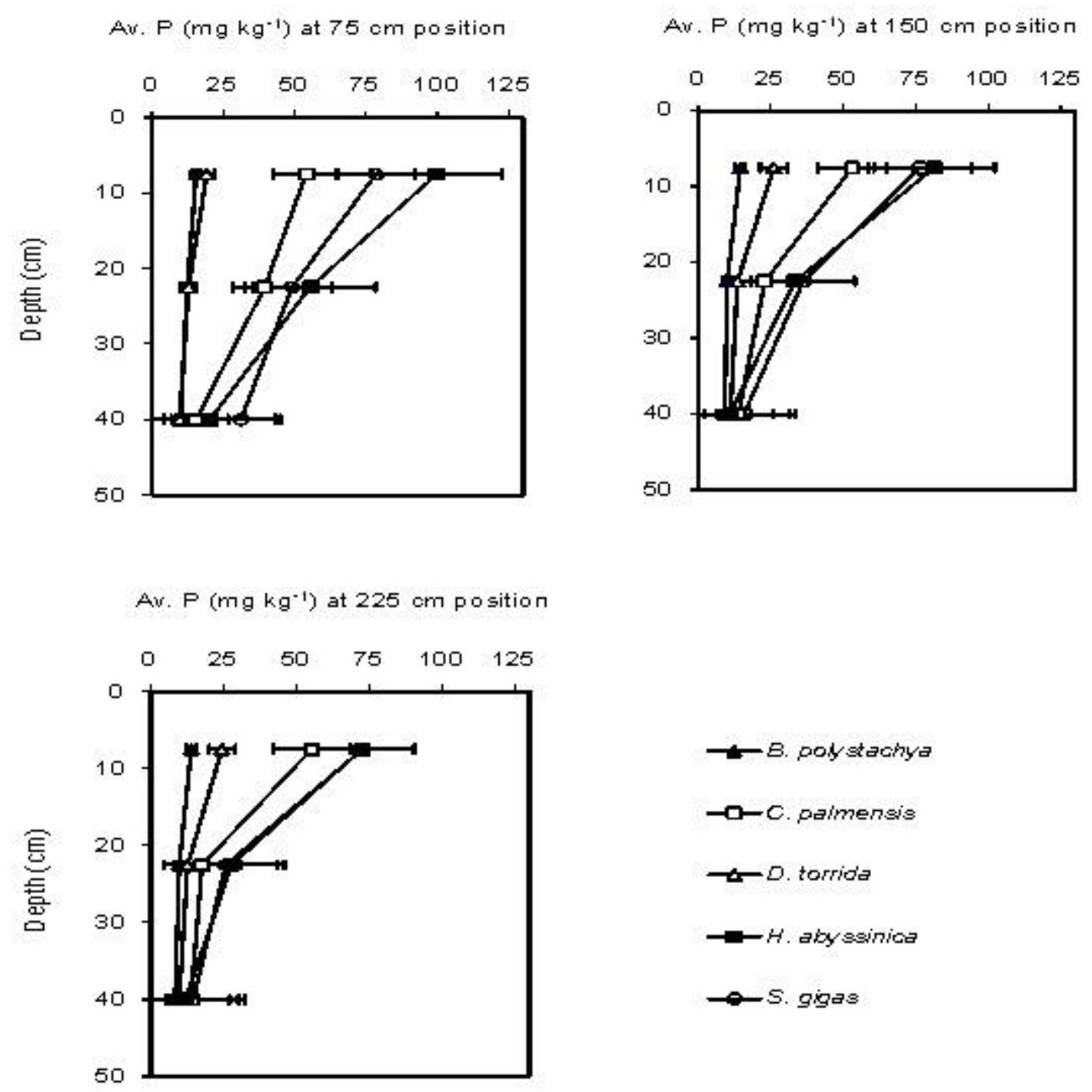

Figure 1. Trends of available P under five tree and shrub species at different soil depths and horizontal positions. Horizontal bars show standard errors of the mean. 
Table 5. Excangeable cations at different depths and positions from five tree and shrub species.

\begin{tabular}{|c|c|c|c|c|c|c|c|c|c|c|}
\hline \multirow[b]{2}{*}{ Species } & \multirow{2}{*}{$\begin{array}{c}\text { Depth } \\
(\mathrm{cm})\end{array}$} & \multicolumn{3}{|l|}{$\mathrm{K}\left(\mu \mathrm{g} \mathrm{g}^{-1}\right)$} & \multicolumn{3}{|l|}{$\mathrm{Ca}\left(\mu \mathrm{gg}^{-1}\right)$} & \multicolumn{3}{|l|}{$\operatorname{Mg}\left(\mu g g^{-1}\right)$} \\
\hline & & $75 \mathrm{~cm}$ position & $150 \mathrm{~cm}$ position & $225 \mathrm{~cm}$ position & $75 \mathrm{~cm}$ position & $150 \mathrm{~cm}$ position & $225 \mathrm{~cm}$ position & $75 \mathrm{~cm}$ position & $150 \mathrm{~cm}$ position & $225 \mathrm{~cm}$ position \\
\hline B. polystachya & 15 & $826^{\mathrm{b}}$ & $568^{a}$ & $455^{c}$ & $845^{b}$ & $736^{\mathrm{b}}$ & $707 \mathrm{~b}$ & $169^{b}$ & $155^{\mathrm{b}}$ & $146^{\mathrm{b}}$ \\
\hline C. palmensis & & $1428^{\mathrm{ba}}$ & $1409^{a}$ & $1291 \mathrm{bac}$ & $1106^{\mathrm{ba}}$ & $1056^{\mathrm{ba}}$ & $1100^{\text {ba }}$ & $189^{b}$ & $181^{b}$ & $211^{\mathrm{ba}}$ \\
\hline D. torrida & & $927^{\mathrm{b}}$ & $771^{\mathrm{a}}$ & $639^{\mathrm{bc}}$ & $982^{\mathrm{ba}}$ & $853^{\mathrm{b}}$ & $782^{\mathrm{b}}$ & $203^{b}$ & $183^{b}$ & $143^{\mathrm{b}}$ \\
\hline H. abyssinica & & $1929^{\mathrm{ba}}$ & $1592^{a}$ & $1642^{a}$ & $1637^{a}$ & $1476^{a}$ & $1869^{a}$ & $369^{a}$ & $339^{a}$ & $327^{a}$ \\
\hline S. gigas & & $2306^{a}$ & $1518^{a}$ & $1507^{\mathrm{ba}}$ & $1580^{a}$ & $1529^{a}$ & $1527^{\mathrm{ba}}$ & $305^{\mathrm{ba}}$ & $251^{\mathrm{ba}}$ & $251^{\mathrm{ba}}$ \\
\hline SEM & & 215.11 & 175.62 & 167.27 & 120.27 & 110.68 & 160.04 & 27.47 & 25.14 & 24.72 \\
\hline B. polystachya & 30 & $489^{a}$ & $444^{a}$ & $424^{a}$ & $686^{a}$ & $592^{c}$ & $621^{c}$ & $145^{\mathrm{a}}$ & $147^{a}$ & $147 \mathrm{ba}$ \\
\hline C.palmensis & & $1171^{a}$ & $1154^{a}$ & $1389^{a}$ & $994^{a}$ & $747 \mathrm{bc}$ & $783^{\mathrm{bc}}$ & $181^{a}$ & $139^{a}$ & $157^{\mathrm{ba}}$ \\
\hline D. torrida & & $539^{a}$ & $531^{a}$ & $482^{a}$ & $738^{a}$ & $682^{\mathrm{bc}}$ & $689^{c}$ & $136^{a}$ & $133^{a}$ & $125^{\mathrm{b}}$ \\
\hline H. abyssinica & & $1483^{a}$ & $1205^{a}$ & $1324^{a}$ & $1364^{a}$ & $1110^{\mathrm{ba}}$ & $1266^{a}$ & $268^{a}$ & $249^{a}$ & $272^{a}$ \\
\hline S. gigas & & $1544^{a}$ & $1259^{a}$ & $1222^{a}$ & $1368^{a}$ & $1277^{a}$ & $1201^{\mathrm{ba}}$ & $242^{a}$ & $242^{a}$ & $235^{\mathrm{ba}}$ \\
\hline SEM & & 183.33 & 178.74 & 183.44 & 115.19 & 89.44 & 88.80 & 23.18 & 20.26 & 22.53 \\
\hline B. polystachya & 50 & $339^{a}$ & $480^{\mathrm{a}}$ & $470^{a}$ & $640^{\mathrm{b}}$ & $556^{a}$ & $666^{a}$ & $148^{\mathrm{ba}}$ & $130^{\mathrm{b}}$ & $148^{\mathrm{b}}$ \\
\hline C. palmensis & & $840^{a}$ & $876^{a}$ & $915^{a}$ & $631^{\mathrm{b}}$ & $622^{a}$ & $652^{a}$ & $127^{b}$ & $121^{\mathrm{b}}$ & $137^{b}$ \\
\hline D. torrida & & $343^{a}$ & $325^{a}$ & $344^{a}$ & $667 \mathrm{~b}$ & $596^{a}$ & $659^{a}$ & $136^{\mathrm{ba}}$ & $131^{b}$ & $137 \mathrm{~b}$ \\
\hline H. abyssinica & & $1048^{a}$ & $938^{a}$ & $1141^{a}$ & $982^{\mathrm{ba}}$ & $1024^{a}$ & $1138^{a}$ & $228^{\mathrm{ba}}$ & $195^{\mathrm{ba}}$ & $200^{\text {ba }}$ \\
\hline S. gigas & & $1372^{a}$ & $1232^{a}$ & $1197 \mathrm{a}$ & $1363^{a}$ & $1055^{a}$ & $991^{a}$ & $268^{a}$ & $265^{a}$ & $277^{a}$ \\
\hline SEM & & 166.41 & 158.13 & 157.64 & 89.72 & 85.50 & 82.91 & 22.49 & 21.31 & 18.50 \\
\hline
\end{tabular}

Means with different letters within a column at similar depth and position are significantly different $(p<0.05)$.

SEM - Standard error of the means $(n=15)$. 
Table 6. Correlations between selected soil attributes for the five tree and shrub species.

\begin{tabular}{|c|c|c|c|c|c|c|c|}
\hline $\begin{array}{l}\text { Depths and } \\
\text { positions } \\
(\mathrm{cm})\end{array}$ & $\begin{array}{c}\text { Tot. } \mathrm{N} \\
\text { vs } \\
\mathrm{OC}\end{array}$ & $\begin{array}{c}\text { pH } \\
\text { vs } \\
\text { Tot. } \mathrm{N}\end{array}$ & $\begin{array}{l}\mathrm{pH} \\
\text { vs } \\
\mathrm{OC} \\
\end{array}$ & $\begin{array}{c}\mathrm{pH} \\
\text { vs } \\
\text { Exch. Al }\end{array}$ & $\begin{array}{c}\mathrm{pH} \\
\text { vs } \\
\text { Exch. Mn }\end{array}$ & $\begin{array}{l}\mathrm{pH} \\
\text { vs } \\
\mathrm{BS}\end{array}$ & $\begin{array}{c}\mathrm{pH} \\
\text { vs } \\
\mathrm{CEC} \\
\end{array}$ \\
\hline 0 to 15 and 75 & $0.841^{* * *}$ & $0.640^{* *}$ & $0.630^{* *}$ & $-0.510^{*}$ & $-0.768^{* * *}$ & $0.918^{* * *}$ & $0.944^{* * *}$ \\
\hline 0 to 15 and 150 & $0.954^{* * *}$ & $0.512^{*}$ & 0.449 & -0.450 & $-0.706^{* * *}$ & $0.897^{* * *}$ & $0.929^{* * *}$ \\
\hline 0 to 15 and 225 & $0.974^{* * *}$ & 0.410 & 0.407 & -0.468 & $-0.8089^{* * *}$ & $0.897^{* * *}$ & $0.964^{* * *}$ \\
\hline 15 to 30 and 75 & $0.984^{* * *}$ & 0.357 & 0.447 & -0.415 & $-0.706^{* * *}$ & $0.880^{* * *}$ & $0.921^{* * *}$ \\
\hline 15 to 30 and 150 & $0.937^{* * *}$ & 0.031 & 0.043 & -0.243 & $-0.726^{* * *}$ & $0.888^{* * *}$ & $0.924^{* * *}$ \\
\hline 15 to 30 and 225 & $0.968^{* * *}$ & -0.032 & 0.002 & -0.313 & $-0.703^{* * *}$ & $0.838^{* * *}$ & $0.921^{* * *}$ \\
\hline 30 to 50 and 75 & $0.972^{* * *}$ & 0.256 & 0.315 & -0.185 & $-0.607^{*}$ & $0.811^{* * *}$ & $0.883^{* * *}$ \\
\hline 30 to 50 and 150 & $0.969^{* * *}$ & 0.067 & 0.072 & -0.212 & $-0.654^{* * *}$ & $0.848^{* * *}$ & $0.907^{* * *}$ \\
\hline 30 to 50 and 225 & $0.940^{* * *}$ & 0.322 & 0.252 & -0.229 & $-0.695^{* * *}$ & $0.815^{* * *}$ & $0.925^{* * *}$ \\
\hline
\end{tabular}

Tot. $N$ - total N, OC - organic C, Exch. Al - exchangeable Al, Exch. $M n$ - exchangeable $M n$, $B S$ - base saturation, $C E C$ - cation exchange capacity

${ }^{*} P<0.05,{ }^{*} P<0.01$ and ${ }^{* * *} P<0.001$ (level of significances)

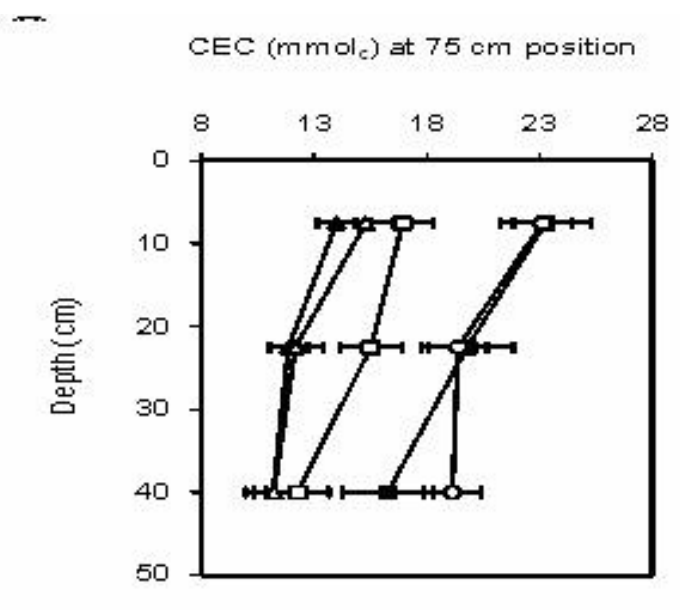

\section{CEC $\left(\mathrm{mmol}_{\mathrm{c}}\right)$ at $150 \mathrm{~cm}$ position}

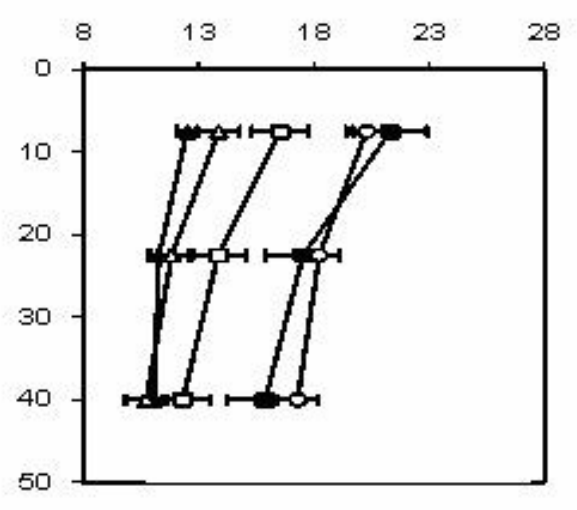

CEC $\left(\mathrm{mmol}_{\mathrm{c}}\right)$ at $225 \mathrm{~cm}$ position
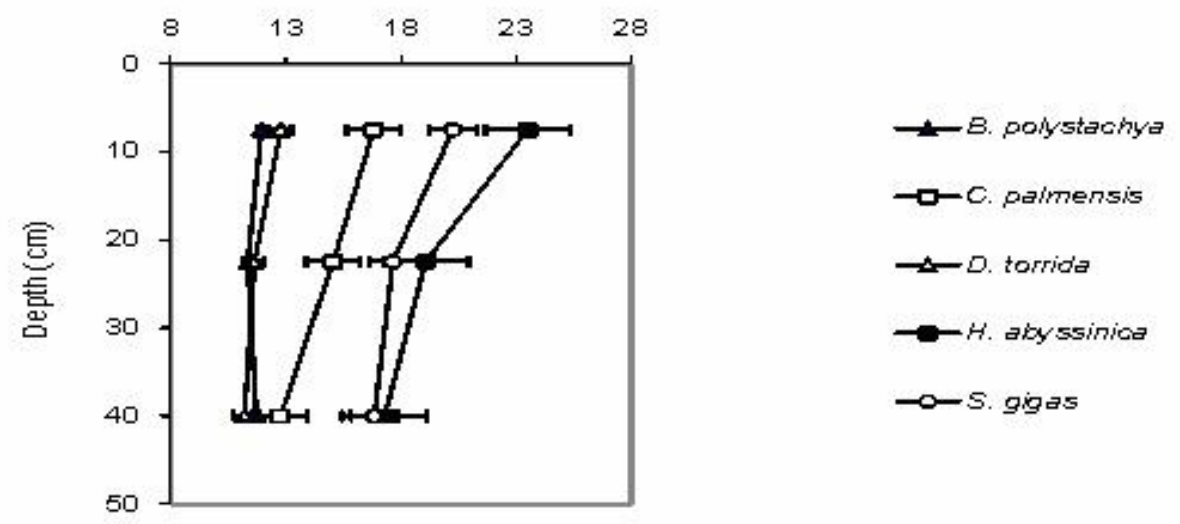

Figure 2. Trends of CEC of the soil under five tree and shrub species at different soil depths and horizontal positions. Horizontal bars show standard errors of the mean. 


\section{Discussion}

Tree and shrub species can differ in their effect on soil properties through various mechanisms, including rates of nutrient inputs, outputs, and cycling. The high content of $\mathrm{OC}$ and $\mathrm{N}$ under $H$. abyssinica as compared to $B$. polystachya could be due to the addition of higher organic resources of the former than the later. Hagenia abyssinica constantly sheds high amount of leaves and provides mulch and green manure to the soil within its vicinity. Kindu et al. (2006b) reported the presence of high amount of litter deposition under 64 months old $H$. abyssinica and Grevillea robusta on Nitisols of central Ethiopia. Dombeya torrida, S. gigas and C. palmensis shed substantial amount of leaves even though their leaf shedding pattern is not as regular as that of $H$. abyssinica.

Farmers in the highlands of central Ethiopia rake the excess foliage litter under $H$. abyssinica, D. torrida and $S$. gigas trees and use them as organic fertilizer source for the nearby crop fields. However, $H$. abyssinica, D. torrida and S. gigas as non $\mathrm{N}$-fixing tree species only cycling the $\mathrm{N}$ present in the soil, not adding $\mathrm{N}$ inputs to the system, as happens through biological nitrogen fixation (BNF) in $C$. palmensis. Non $\mathrm{N}$-fixing tree and shrubs species in general obtain their $\mathrm{N}$ and other nutrients through effective retrieval from the soil (Jama et al., 2000).

The contents of $\mathrm{P}, \mathrm{K}, \mathrm{Ca}$ and $\mathrm{Mg}$ in the soil under $H$. abyssinica, $S$. gigas and $C$. palmensis were relatively high as compared to the other species considered for the present study (Table 5 and Figure 2). Enrichment of these nutrients under the three species could be associated to the rooting system and efficient nutrient cycling power of the trees. Deep-rooted trees and shrubs often act as 'nutrient pumps', taking nutrients from deep subsoil horizons into their root systems, translocating it to their leaves, and recycling it back to the surface of the soil via leaf fall and leaching (Kindu et al., 1997, 1999; Berger et al., 2006). Hence, the cycling of essential nutrients maintains an abundant supply of nutrients for incorporation into new biomass while at the same time limiting nutrient losses from the soil profile.

The soil under B. polystachya had the lowest nutrient content as compared to all other indigenous and exotic species included in the present study. The low soil nutrient content under $B$. polystachya can be related to the very low leaf shedding characteristics of the species. As a result of low leaf shedding, the nutrient gain of the soil system under B. polystachya through litter fall can be inadequate. It is likely to notice the positive impact of the B. polystachya through chopping and incorporating the green biomass of the tree into the soil system. Buddleja polystachya readily coppice and provide substantial amount of green biomass.

Organic C, N, P, K, Ca and Mg progressively declined with depth and horizontal distance from the base of the tree and shrub species. The presence of the tree and shrub species and associated soil enrichment would therefore seem to be restricted to the near surface layers. The effect of the trees on the bulk of the soil in the lower depths was very minimal (Table 3, 5 and Figure 2). The minimal effect for the five tree and shrub species on the soil properties in lower as compared to topsoil depths could be related to young age of the trees. The age of the tree and shrub species included in the present study was between four and nine years (Table 2). Trees can positively influence soil properties in lower soil depths during many years of their below and aboveground growth (Pandey et al., 2000; Chang et al., 2002). Improvement of soil nutrients in the upper soil depths and close to the tree stems has been reported to various tree and shrub species (Yeshanew et al., 1999; Tadesse et al., 2000; Abebe et al., 2001; Gindaba et al., 2005).

The soil $\mathrm{pH}$ under $H$. abyssinica and $S$. gigas was high as compared to the soil $\mathrm{pH}$ under other species (Table 3). The elevated soil $\mathrm{pH}$ under the two species could be a result from increased base cation cycling and subsequent enrichment of the base status of the underneath soil. The presences of higher level of exchangeable base forming cations contribute to the amelioration of soil acidity (Brady, 1990). Our findings on the levels of $\mathrm{K}, \mathrm{Ca}, \mathrm{Mg}$ and $\mathrm{Na}$ under $H$. abyssinica and $S$. gigas are in accordance with the investigation of Sae-Lee et al. (1992) and Tadesse et al. (2000).

The level of CEC under the five species was slightly higher in the top $0-15 \mathrm{~cm}$ soil depth than in the lower 15 30 and $30-50 \mathrm{~cm}$ soil depths (Figure 2). Likewise, the soil under $H$. abyssinica and $S$. gigas depicted relatively more CEC than under other species. Like the contents of base cations, higher level of CEC under the two species could be due to greater amount of litter deposition. The level of CEC varies with changes in soil $\mathrm{pH}$, organic matter, and clay content. Cation exchange capacity provides a reservoir of nutrients to replenish nutrients that can be removed from the soil water by plant uptake and leaching (Camberato, 2001).

Total soil $\mathrm{N}$ was positively and strongly correlated with OC under the five tree and shrub species. Such a correlation of $\mathrm{N}$ with $\mathrm{OC}$ was expected as the amount of the former parallels with soil organic matter (Schlesinger, 1997; Brady and Weil, 2002). Similarly, soil pH was positively related with $\mathrm{BS}$ and $\mathrm{CEC}$ while negatively related with $\mathrm{Al}$ and $\mathrm{Mn}$. Soil $\mathrm{pH}$ drops as acidic $\mathrm{H}$ and $\mathrm{Al}$ cation in the exchange sites increases and basic $\mathrm{Ca}, \mathrm{Mg}$ and $\mathrm{K}$ cation decreases (Brady and Weil, 2002).

\section{Conclusions}

The soil under $H$. abysinica, $S$. gigas and $C$. palmensis retained a substantial amount of plant nutrients. This is an indication of the species potential to protect the loss of nutrients and thereby contribute to long-term ecosystem sustainability. Hence, the planting efforts of $H$. abyssinica, $S$. gigas and $C$. palmensis should be strengthened in different land-use systems of the high altitude areas.

\section{Acknowledgements}

The authors would like to thank the Austrian Development Cooperation, the Commission for Development Studies at the Austrian Academy of Sciences (KEF), the African Forestry Research Network (AFORNET) and the Ethiopian Institute of Agricultural Research (EIAR) for the financial assistance that has supported this work. We would also like to express our gratitude to the Institute of Forest Ecology and Institute of Applied Geology at UNI-BOKU in Austria for the laboratory analysis of soil samples. The support from staffs of forestry, soil and water management research divisions at Holetta, and farmers and development agents in the Galessa-Jeldu areas are highly appreciated. We thank anonymous reviewers for their constructive comments. 


\section{References}

Abebe, Y., Fissaha, I. and Olsson, M. 2001. Contribution of indigenous trees to soil properties: the case of scattered trees of Cordia africana Lam. in croplands of western Oromia. Ethiopian Journal of Natural Resources 3: 245-270.

Amare, H., Priess, J. A., Veldkamp, E. and Lesschen, J. P. 2006. Smallholders' soil fertility management in the central Highlands of Ethiopia: implications for nutrient stocks, balances and sustainability of agroecosystems. Nutrient Cycling in Agroecosystems 75: 135-146.

Berger, T. W., Swoboda, S., Prohaska, T. and Glatzel, G. 2006. The role of calcium uptake from deep soils for spruce (Picea abies) and beech (Fagus sylvatica). Forest Ecology and Management 229: 234-246.

Berhane, K., Kindu, M., Fekede, F. and Chilot, Y. 2006. Agroforestry practices, opportunities and research needs in the highlands of Dendi wereda, Ethiopia. In: Tilahun, A., German, L., Opondo, C., Rao, S. and Stroud, A. (eds.). Integrated Natural Resource Management in Practice. Enabling Communities to Improve Mountain Livelihoods and Landscapes. African Highlands Initiative, Kampala, Uganda, pp. 132-138.

Brady, N. C. 1990. The Nature and Properties of Soils. 10 edition. Macmillan Publishing Company, New York.

Brady, N. C. and Weil, R. R. 2002. The Nature and Properties of Soils. Pearson Education, Inc., New Jersey.

Camberato, J. J. 2001. Cation exchange capacityEverything you want to know and much more. Clemson University, Crop and Soil Environmental Science,USA.http://virtual.clemson.edu/groups/turf ornamental/tmi/fertlime/Cation $\% 20$ exchange $\% 20 \mathrm{ca}$ pacity.pdf. (Accessed on September 20, 2007.)

Chang, S. X., Amatya, G., Beare, M. H. and Mead, D. J. 2002. Soil properties under a Pinus radiata - ryegrass silvopastoral system in New Zealand. Part I. Soil N and moisture availability, soil $\mathrm{C}$, and tree growth. Agroforestry Systems 54: 137-147.

German, L. A., Berhane, K. and Kindu, M. 2005. Watershed management to counter farming systems decline: toward a demand-driven, systems-oriented research agenda. Agricultural Research and Extension Network, Network Paper No. 145.

Gindaba, J., Rozanov, A. and Legesse, N. 2005. Trees on farms and their contribution to soil fertility parameters in Badessa, eastern Ethiopia. Biology and Fertility of Soils 42: 66-71.

ICRAF (International Center for Research in Agroforestry). 1990. Agroforestry: Potentials and research needs for the Ethiopian highlands. AFRENA report no. 21, Nairobi, Kenya.

Jama, B., Palm, C. A., Buresh, R. J., Niang, A., Gachengo, C., Nziguheba, G. and Amadalo, B. 2000. Tithonia diversifolia as a green manure for soil fertility improvement in western Kenya: a review. Agroforestry Systems 49: 201-221.

Kindu, M., Buresh, R. J. and Jama, B. 1997. Root and inorganic nitrogen distributions in sesbania fallow, natural fallow and maize fields. Plant and Soil 188: 319-327.

Kindu, M., Buresh, R. J., Richard, C. and Kipleting, K. M. 1999. Root length and nitrate under Sesbania: Vertical and horizontal distribution and variability. Agroforestry Systems 42: 265-282.
Kindu, M., Glatzel, G. and Sieghardt, M. 2006a. Evaluation of common indigenous tree and shrub species for soil fertility improvement and fodder production in the highland areas of western Shewa, Ethiopia. In: Glatzel, G. and Habermann, B. (eds.). Gemeinsam Forschen gemeinsam LernenForschungspartnerschaften in der Entwicklungszusammenarbeit. Österreichischen Akademie der Wissenschaften, Wien. pp.99-106.

Kindu, M., Glatzel, G., Tadesse, Y. and Yosef, A. 2006b. Tree species screened on Nitisols of central Ethiopia: biomass production, nutrient contents and effect on soil nitrogen. Journal of Tropical Forest Science 18: 173180.

Olsen, S. R. and Sommers, L. E. 1982. Phosphorus. In: Page, A. L., Miller, R. H. and Keeney, D. R. (eds.). Methods of Soil Analysis; Part 2. Chemical and Microbiological Properties. Soil Science Society of America, Madison, WI, USA, pp. 403-430.

ÖNORM (Österreichisches Normungsinstitut) L1080. 2005. Chemical analysis of soils; determination of humus by dry combustion of carbon. Austrian Standards Institute.

ÖNORM (Österreichisches Normungsinstitut) L1082. 2005. Chemical analysis of soils; determination of total nitrogen. Austrian Standards Institute.

ÖNORM (Österreichisches Normungsinstitut) L1083. 2005. Chemical analysis of soils; determination of acidity ( $\mathrm{pH}$ value). Austrian Standards Institute.

ÖNORM (Österreichisches Normungsinstitut) L1085. 2004. Chemical analysis of soils; determination of mineral nutritive and toxic element in acid digests. Austrian Standards Institute.

Pandey, C. B., Singh, A. K. and Sharma, D. K. 2000. Soil properties under Acacia nilotica trees in a traditional agroforestry system in central India. Agroforestry Systems 49: 53-61.

Poschen, P. 1986. An evaluation of the Acacia albidabased agroforestry practices in the Harerghe highlands of eastern Ethiopia. Agroforestry Systems 4: 129-143.

Power, I. L., Thorrold, B. S. and Balks, M. R. 2003. Soil properties and nitrogen availability in silvopastoral plantings of Acacia melanoxylon in north Island, New Zealand. Agroforestry Systems 57: 225-237.

Sae-Lee, S., Vityakon, P. and Prachaiyo, B. 1992. Effects of trees on paddy bund on soil fertility and rice growth in northeast Thailand. Agroforestry Systems 18: 213-223.

SAS (Statistical Analysis System Institute). 1999. SAS/STAT User's Guide, Version 8. SAS Institute Inc., Cary, NC, USA.

Schlesinger, W. H. 1997. Biogeochemistry: An analysis of global change. Academic Press, San Diego.

Tadesse, H., Legesse, N. and Olsson, M. 2000. Millettia ferruginea from southern Ethiopia: impacts on fertility and growth of maize. Agroforestry Systems 48: 9-24.

Wezel, A. 2000. Scattered shrubs in pearl millet fields in semiarid Niger: effect on millet production. Agroforestry Systems 48: 219-228.

Yeshanew, A., Tekaligne, M. and Olsson, M. 1999. Changes in some soil chemical properties under scattered Croton macrostachyus trees in the traditional agroforestry system in northwestern Ethiopia. Ethiopian Journal of Natural Resources 1: 215-233. 